\title{
Implementasi Model Pembelajaran Berbasis Proyek Dalam Praktikum untuk Meningkatkan Intensi Berwirausaha Mahasiswa
}

\author{
Ruhana Afifi ${ }^{1)}$, Lia Yulisma ${ }^{2)}$ \\ 12 Pendidikan Biologi FKIP Universitas Galuh, Jl. R.E Martadinata No. 150, Ciamis. \\ Email : ruhanaafifi@yahoo.com \\ Email: goli_yulisma31@yahoo.co.id
}

APA Citation: Afifi, R., \& Yulisma, L. (2020). Implementasi Model Pembelajaran Berbasis Proyek Dalam Praktikum untuk Meningkatkan Intensi Berwirausaha Mahasiswa. Quagga: Jurnal Pendidikan dan Biologi, 12(1), 17-23. doi: 10.25134/quagga.v12i1.2127.

Received: 06-11-2019

Accepted: $30-12-2019$

Published: 23-01-2020

\begin{abstract}
Abstrak: Tujuan penelitian ini untuk menganalisis peningkatan intensi berwirausaha mahasiswa yang mengikuti pembelajaran berbasis proyek melalui praktikum budidaya maggot Black Soldier Fly (BSF). Subjek penelitian ini adalah mahasiswa calon guru biologi semester enam tahun akademik 2018-2019 dengan pengambilan sampel menggunakan teknik cluster random sampling Penelitian yang dilakukan adalah quasi eksperimen dengan pengujian hipotesis uji satu pihak berdasarkan skor pretest dan posttest. Adapun data yang dikumpulkan, yaitu intensi berwirausaha dengan menggunakan kuesioner. Hasil analisis menunjukkan terdapat peningkatan intensi berwirausaha mahasiswa kelas eksperimen yang tinggi (28,57\%), berbeda signifikan dengan kelas kontrol. Artinya, penerapan model pembelajaran berbasis proyek pada praktikum budidaya Maggot BSF dapat meningkatkan intensi berwirausaha mahasiswa.
\end{abstract}

Kata Kunci : Pembelajaran Berbasis Proyek; Praktikum; Maggot BSF; Intensi Berwirausaha

\begin{abstract}
This research aims to analyze entrepreneurial intentions of students who join Project-Based Learning in practice maggot Black Soldier Fly (BSF) cultivation. The subject of this research is the 6thsemester students of Biology Education in the academic year 2018-2019 with cluster random sampling. This study is Quasi-Experimental by testing the one-party test hypotheses based on pretest and posttest score. Therefore, the data entrepreneurial intentions collected by questionnaire. The result shows that the entrepreneurial intentions increase highly significant (28,57\%), different with control class. This is indicated that implementation of Project-Based Learning in Maggot BSF cultivation practice can improve student's entrepreneurial intentions.
\end{abstract}

Keywords: Project-Based Learning; Practice; Maggot BSF; entrepreneurial intentions

\section{PENDAHULUAN}

Saat ini persaingan mendapatkan pekerjaan sangat ketat. Salah satu cara perguruan tinggi untuk mensiasati kondisi ini, yaitu dengan menciptakan mahasiswa yang siap berwirausaha setelah menyelesaikan pendidikannya. Diperlukan upaya meningkatkan intensi berwirausaha mahasiswa untuk mendorong lahirnya wirausahawirausaha muda yang potensial berbekal keahlian dalam bidang ilmu yang dimilikinya.

Intensi berwirausaha adalah keinginan atau niat yang ada pada diri seseorang menampilkan perilaku berwirausaha agar dapat memanfaatkan peluang, menjadi seorang yang kreatif dan mandiri serta mampu mengolah sumber daya yang ada (Suharti dan Hani, 2011). Intensi berwirausaha merupakan probabilitas subjektif seseorang yang terlibat dalam kewirausahaan untuk menciptakan suatu perusahaan atau lapangan pekerjaan baru (Bae et.al, 2014). Semakin besar intensi berwirausaha seseorang maka semakin besar pula peluang untuk mencapai tujuan usahanya (Muhar, 2013). Intensi berwirausaha pada diri seseorang dapat dilatihkan melalui kegiatan yang relevan disertai praktik sehingga dapat mengasah keterampilanya melalui pengalaman 
langsung (Gerba, 2012). Melatihkan kegiatankegiatan yang dapat meningkatkan adversity quotient, self-efficacy, dan need for achievement secara simultan dapat membentuk intensi berwirausaha mahasiswa ( Handaru, et al., 2015 ).

Standar proses pembelajaran di LPTK sebagai tempat pembentukan mahasiswa calon guru seperti tercantum dalam Permendikbud No.49 tahun 2014 tentang Standar Nasional Pendidikan Tinggi (SNPT) dan Kualifikasi standar lulusan perguruan tinggi tercantum dalam Perpres No. 08 tahun 2012 tentang Kerangka Kualifikasi Nasional Indonesia (KKNI) harus mengacu pada capaian pembelajaran (learning outcomes). Capaian tersebut merupakan internalisasi dan akumulasi ilmu pengetahuan, keterampilan, sikap, dan kompetensi dalam suatu bidang ilmu/keahlian tertentu sesuai dengan (Otaya, 2014). Berdasarkan hal tersebut proses pembelajaran di jurusan Pendidikan Biologi harus menggunakan metode yang efektif sehingga mahasiswa calon guru biologi memperoleh keterampilan dalam bidang biologi terapan salah satunya melalui praktikum.

Praktikum merupakan metode yang mengarahkan mahasiswa belajar berdasarkan pengalaman konkret sehingga memperoleh kesempatan untuk menguji dan melaksanakan teori dalam keadaan nyata (Agustina, 2015). Saat ini, praktikum yang dilakukan masih konvensional bersifat latihan dengan panduan lembar kegiatan yang sudah ada, tidak melibatkan mahasiswa dalam perencanaan praktikum dan merancang eksperimen sehingga mahasiswa merasa tidak tertantang untuk melakukan inovasi.

Upaya yang dapat dilakukan untuk mengatasi permasalahan tersebut adalah dengan menerapkan model pembelajaran berbasis proyek dalam praktikum. Menurut Blank dan Harwell pembelajaran berbasis proyek adalah salah satu model pembelajaran otentik yang langkah-langkahnya dapat melatih kemampuan dan keterampilan mahasiswa merencanakan, mengimplementasikan dan mengevaluasi proyek dalam dunia nyata sehingga memfasilitasi mahasiswa untuk berpikir kreatif dan melakukan inovasi (Bas, 2011).
Pada penelitian ini praktikum biologi terapan yang dilakukan adalah budidaya Maggot BSF atau lalat tentara hitam (Hermetia illucens). Lalat ini berasal dari Amerika dan selanjutnya tersebar ke berbagai wilayah di dunia. Lalat ini mampu tumbuh dan berkembang biak dengan mudah, dapat dipelihara pada media limbah organik dan berperan sebagai agen biokonversi pengurai sampah organik (Čičková H, et.al. 2015). Maggot BSF memiliki kandungan protein yang tinggi sehingga dapat dijadikan pakan ternak (Wardhana, 2016).

Budidaya Maggot BSF memiliki potensi yang sangat besar untuk dikembangkan karena permintaan dan harga jual tinggi di pasaran namun ketersediaanya masih sangat terbatas. Produk hasil pembelajaran berbasis proyek yang didapatkan adalah media budidaya Maggot BSF dengan berbagai variasi limbah organik yang digunakan sebagai hasil dari proyek diantaranya limbah sayuran, limbah sampah pasar, limbah buah-buahan, limbah serbuk gergaji. Media hasil proyek tersebut efektif untuk meningkatkan produk maggot BSF ditinjau dari efektifitas media dalam meningkatkan bobot basah, panjang dan kepadatan populasi Maggot BSF. Produk yang dihasilkan dapat diterapkan sebagai inovasi media budidaya Maggot BSF selain dapat dijadikan peluang untuk berwirausaha juga dapat diterapkan kepada masyarakat untuk menambah pendapatan dan sebagai solusi terhadap permasalahan sampah.

Implementasi model pembelajaran berbasis proyek dalam praktikum memberikan kebebasan bagi mahasiswa untuk merencanakan eksperimen, memilih bahan dan alat yang digunakan, serta membuat sendiri prosedur yang dilakukan sehingga mahasiswa dapat melakukan berbagai inovasi berdasarkan hasil investigasi. Menurut The George Lucas Educational Foundation (Kemdikbud, 2014), model pembelajaran berbasis proyek memiliki sintaks: 1) Pembelajaran di awali dengan memberikan pertanyaan sehingga merangsang mahasiswa untuk mencari jawabannya, mengambil topik yang relevan dengan realitas dunia nyata dan investigasi mendalam. 2) Perencanaan proyek secara berkelompok dan 
pemilihan aktivitas yang mampu mendukung mahasiswa dalam menentukan jawaban pertanyaan yang esensial, mengetahui alat dan bahan serta prosedur yang dapat diakses untuk membantu penyelesaian proyek. 3). Mahasiswa mengatur jadwal aktivitas dalam menyelesaikan proyek. 4). Dosen melakukan pemantauan terhadap aktivitas mahasiswa selama proses penyelesaian proyek. 5). Penilaian dilakukan untuk membantu dosen dalam mengukur ketercapaian standar, mengevaluasi kemajuan mahasiswa, memberi umpan balik tingkat pemahaman mahasiswa, dan menyusun strategi pembelajaran selanjutnya. 6). Mahasiswa dan dosen melakukan refleksi terhadap aktivitas dan hasil proyek yang sudah dilaksanakan.

Model pembelajaran berbasis proyek efektif untuk meningkatkan sikap kewirausahaan, minat dan motivasi berwirausaha serta prestasi belajar (Mulyani, 2014; Afifi dan Yulisma, 2019; Jagantara et.al, 2014). Begitu pula beberapa penelitian menyatakan bahwa pembelajaran berbasis proyek dapat menumbuhkan semangat wirausaha, keinginan untuk berwirausaha dan capaian hasil belajar kewirausahaan mahasiswa pendidikan ekonomi (Farida, et.al, 2017; Darmawan dan Suetjipto, 2016). Sejalan dengan pernyataan tersebut Afifi dan Yulisma (2019) menyatakan bahwa penerapan model pembelajaran berbasis proyek melalui praktikum pengawetan bahan pangan mampu mengembangkan sikap kewirausahaan dan motivasi berwirausaha mahasiswa.

Berdasarkan uraian di atas tujuan dari penelitian ini adalah untuk mengetahui peningkatan intensi berwirausaha mahasiswa yang memperoleh pembelajaran dengan penerapan model pembelajaran berbasis proyek pada praktikum budidaya Maggot BSF lebih baik daripada praktikum konvensional. Keutamaan penelitian ini juga diharapkan diperoleh produk hasil proyek berupa inovasi media budidaya Maggot BSF untuk meningkatkan produksi Manggot BSF yang dapat diterapkan di masyarakat dalam bentuk kegiatan pengabdian.

\section{METODOLOGI PENELITIAN}

Penelitian ini dilaksanakan pada bulan Mei sampai dengan Agustus tahun 2019. Populasi penelitian ini mahasiswa semester enam jurusan Pendidikan Biologi Universitas Galuh tahun akademik 2018/2019. Pengambilan sampel menggunakan teknik cluster random sampling. Penerapan model Pembelajaran berbasis proyek dalam praktikum budidaya Maggot BSF dilaksanakan di kelas eksperimen sedangkan untuk kelas kontrolnya menggunakan praktikum konvensional.

Instrumen yang digunakan yaitu kuesioner intensi berwirausaha. Indikator dari intensi berwirausaha yang digunakan adalah; 1) siap melakukan segala hal yang diperlukan untuk menjadi wirausaha, 2) bertujuan menjadikan wirausahawan sebagai suatu profesi, 3) berupaya sepenuh hati memulai dan menjalankan usaha sendiri, 4) memutuskan untuk membuat usaha sendiri di masa depan, 5) berpikir serius untuk memulai suatu usaha, dan 6) memiliki niatan kuat untuk menjadi wirausaha di masa depan. Kuesioner terlebih dahulu diujicobakan kepada mahasiswa diluar sampel untuk mengetahui validitas dan realiabilitasnya sehingga didapatkan instrumen yang layak. Hasil uji instrumen utama kuesioner intensi berwirausaha diperoleh 25 item pernyataan yang valid dan reliabel.

Kuesioner digunakan sebagai bahan pretest dan posttest. Tahapan penelitiannya adalah pretest diberikan di awal sebelum dilaksanakan pembelajaran. Selanjutnya, dilaksanakan pembelajaran dengan penerapan model pembelajaran berbasis proyek dalam praktikum di kelas eksperimen dan pembelajaran praktikum konvensional di kelas kontrol. Setelah pembelajaran selesai, mahasiswa mengikuti posttest. Jenis penelitian yang digunakan yaitu quasi eksperimen dengan pengujian hipotesis uji satu pihak. Langkah analisis data adalah menentukan skor gain ternormalisasi (N-gain) intensi berwirausaha dari skor pretest dan posttest untuk kelas eksperimen maupun kelas kontrol, selanjutnya uji normalitas pada skor $\mathrm{N}$-gain dengan uji One-Sample Kolmogorov-Smirnov Test. Skor $\mathrm{N}$-gain berdistribusi normal maka dilanjutkan dengan uji parametrik yaitu uji homogenitas dengan levene's Test for Equality of Variances. Berdasarkan hasil analisis terbukti homogen maka dilanjutkan dengan uji t. Perbandingan 
Quagga: Jurnal Pendidikan dan Biologi

Volume 12, Nomor 1, Januari 2020, pp.17-23
p-ISSN 1907-3089, e-ISSN2651-5869

https://doi.org/10.25134/quagga.v12i1.2127 besar persentasi mahasiswa yang masuk ke dalam klasifikasi $\mathrm{N}$-gain tinggi, sedang dan rendah menggunakan rumus persentase berdasarkan jumlah mahasiswa. Selanjutnya dilihat persentase mahasiswa mana yang lebih besar antara kelas eksperimen dan kelas kontrol.

\section{HASIL DAN PEMBAHASAN}

Berdasarkan hasil penelitian diperoleh data skor pretest dan posttest intensi berwirausaha mahasiswa, kemudian ditentukan skor gain ternormalisasi (N-gain), selanjutnya dilakukan pengujian hipotesis uji satu pihak dengan menggunakan bantuan software SPSS. Uji normalitas $\mathrm{N}$-gain intensi berwirausaha mahasiswa kelas eksperimen dan kelas kontrol menunjukkan bahwa nilai Asymp.Sig. (2tailed) semua data $>0,05$. Sehingga dapat disimpulkan bahwa semua data tersebut memiliki distribusi normal. Oleh karena itu untuk menguji hipotesis dapat dilakukan dengan menggunakan uji parametrik yaitu uji t independent sample. Uji t digunakan untuk mengetahui perbedaan intensi berwirausaha antara kelas kontrol dan kelas eksperimen. Ringkasan hasil uji t dapat dilihat dalam Tabel 1 .

Tabel 1. Descriptive Statistics Intensi Berwirausaha

\begin{tabular}{lrrrrr}
\hline & N & \multicolumn{1}{c}{ Min } & Max & Mean & Std. Dev \\
\hline Kelas Kontrol & 21 &, 20 &, 72 &, 4343 &, 1388 \\
Kelas Eksperimen & 21 &, 37 &, 77 &, 6148 &, 1049 \\
\hline Valid N (listwise) & 21 & & & & \\
\hline
\end{tabular}

Berdasarkan Tabel 1. diketahui bahwa jumlah data pada kedua kelas adalah 21 orang mahasiswa. Nilai minimum kelas kontrol sebesar 0,20 dan kelas eksperimen 0,37 sedangkan nilai maksimum kelas kontrol sebesar 0,72 dan kelas eksperimen 0,77. Nilai rata-rata intensi berwirausaha mahasiswa atau mean pada kelas kontrol adalah sebesar 0,4343, sementara untuk kelas eksperimen adalah sebesar 0,6148. Dengan demikian secara deskriptif statistik dapat disimpulkan terdapat perbedaan rata-rata intensi berwirausaha antara kelas kontrol dan eksperimen, dan dapat dikatakan bahwa mahasiswa di kelas eksperimen memiliki intensi berwirausaha yang lebih tinggi daripada mahasiswa kelas kontrol.

Selanjutnya untuk membuktikan apakah perbedaan tersebut signifikan (nyata) atau tidak, maka ditentukan dengan uji t independent sample yang disajikan pada Tabel 2 .

Tabel 2. Independent Samples Test Levene's Test for Equality of t-test for Equality Variances of Means

\begin{tabular}{llccrrr} 
& & F & Sig. & t & df & Sig. \\
\hline $\begin{array}{lllll}\text { Intensi } \\
\text { Kewira } \\
\text { usahaan }\end{array}$ & $\begin{array}{l}\text { Equal variances } \\
\text { assumed }\end{array}$ & 2,301 &, 137 & 4,753 & 40 &, 00 \\
& $\begin{array}{l}\text { Equal variances } \\
\text { not assumed }\end{array}$ & & & 4,753 & 37,22 &, 00 \\
\hline
\end{tabular}

Berdasarkan Tabel 2. di atas diketahui bahwa nilai Sig. Levane's test adalah sebesar $0,137>0,05$. Oleh karena itu dapat diartikan bahwa varians data antara kelas kontrol dan eksperimen adalah homogen atau sama. Pada bagian equal variances assumed diketahui nilai sig. (2-tailed) sebesar $0,00<0,05$, atau jika dilihat dari nilai t hitung sebesar 4,753 > t tabel 2,05. Maka sebagaimana dasar pengambilan keputusan dalam uji $t$ independent sample bahwa $\mathrm{H}_{0}$ ditolak dan $\mathrm{H}_{\mathrm{a}}$ diterima. Oleh karena itu dapat disimpulkan bahwa terdapat perbedaan yang signifikan antara rata-rata intensi berwirausaha pada kelas kontrol dengan kelas eksperimen.

Perbandingan besar persentasi mahasiswa yang masuk ke dalam klasifikasi $\mathrm{N}$-gain tinggi, sedang dan rendah menggunakan rumus persentase berdasarkan jumlah mahasiswa dapat dilihat dalam Gambar 1.

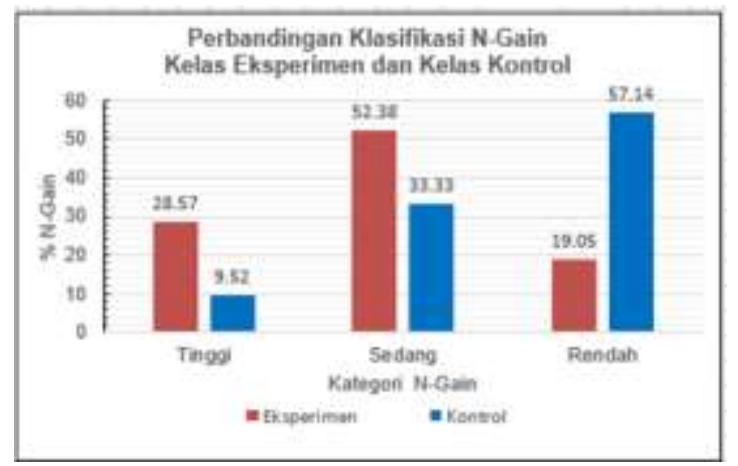

Gambar 1. Grafik Perbandingan Klasifikasi N-

Gain Kelas Eksperimen dan Kelas Kontrol.

Berdasarkan Gambar 1 terlihat mahasiswa yang termasuk ke dalam kategori $\mathrm{N}$-Gain tinggi kelas eksperimen $(28,57 \%)$ lebih tinggi 
dibandingkan dengan kelas kontrol (9,52\%). Kategori N-Gain sedang untuk kelas eksperimen $(52,38 \%)$ lebih tinggi daripada kelas kontrol (33,33\%), sedangkan untuk kategori rendah kelas kontrol $(57,14 \%)$ lebih tinggi dari kelas eksperimen $(19,05 \%)$. Hal ini menunjukkan penerapan model pembelajaran berbasis proyek pada praktikum budidaya Maggot BSF dapat meningkatkan intensi berwirausaha mahasiswa.

Hasil penelitian yang diperoleh menunjukkan peningkatan intensi berwirausaha kelas eksperimen yang diberi perlakuan pembelajaran berbasis proyek pada praktikum budidaya Maggot BSF lebih tinggi dibandingkan dengan kelas kontrol yang melakukan praktikum konvensional.

Kondisi ini terjadi karena pada aktivitas pembelajaran berbasis proyek banyak terlatihkan aspek-aspek intensi berwirausaha diantaranya mahasiswa terlibat dalam investigasi, pemecahan masalah dan kegiatan tugas-tugas bermakna, memberi kesempatan kepada mahasiswa untuk bekerja secara otonom mengkonstruk pengetahuan diri mereka sendiri, serta mencapai puncak menghasilkan produk nyata. Model ini menggambarkan sistem menanamkan kewirausahaan dalam berbagai disiplin ilmu (Siwa et. al, 2013). Kondisi tersebut sejalan dengan Sani (2014) yang menyatakan bahwa kekuatan model pembelajaran berbasis proyek yaitu 1) melibatkan mahasiswa dalam permasalahan dunia yang kompleks sehingga memberikan pengalaman belajar yang lebih bermakna, 2) melibatkan mahasiswa dalam menerapkan pengetahuan dan keterampilan dengan konteks yang bervariasi, 3) memberikan mahasiswa kesempatan untuk mengembangkan keterampilan interpersonal ketika bekerja sama dalam kelompok, 5) melatih keterampilan yang dibutuhkan untuk hidup dan bekerja di masyarakat, dan 6) mencakup aktivitas refleksi pengalaman belajar sehingga bisa dijadikan bahan perbaikan pada pembelajaran selanjutnya.

Implementasi pembelajaran berbasis proyek dalam praktikum memberikan kebebasan bagi mahasiswa untuk merencanakan eksperimen, memilih bahan dan alat yang digunakan, serta membuat sendiri prosedur yang dilakukan sehingga mahasiswa dapat melakukan berbagai inovasi berdasarkan hasil investigasi. Kondisi tersebut sangat mendukung dalam menumbuhkan intensi berwirausaha mahasiswa. Seorang wirausahawan perlu melatih diri secara terstruktur dan intens untuk berinovasi (Suryaman, 2014 ).

Pembelajaran berbasis proyek mendorong mahasiswa untuk berinovasi seperti pada praktikum ini mahasiswa dilatih untuk melakukan perancangan dan pembuatan produk media budidaya Maggot BSF dari berbagai limbah organik yang sering ditemui di lingkungan sekitar. Kondisi tersebut dapat menjadikan mahasiswa terbiasa untuk berinovasi dibidang lainnya (Kusumaningrum dan Djukri, 2016). Ketika ada peristiwa yang dapat memicu, maka intensi akan segera termanifestasi menjadi perilaku kewirausahaan (Singh, Prasad, \& Raut, 2012). " Terdapat pengaruh sosial yang kuat terhadap intensi seseorang dengan melihat pengalaman orang lain, individu dapat tergerak untuk menjalankan usaha (Mulyana, 2012).

Adapun pelaksanaan pembelajaran di kelas kontrol menggunakan praktikum konvensional. Mahasiswa membuat media budidaya Maggot BSF berdasarkan prosedur praktikum yang sudah disediakan oleh dosen. Secara teoritis pelaksanaan praktikum dapat mengembangkan potensi mahasiswa dalam menguasai kemampuan kognitif, psikomotor dan sikap. Namun pada kenyataannya di lapangan kegiatan praktikum masih terbatas pada jenis praktikum latihan. Tujuan dari praktikum ini untuk mengembangkan keterampilan dasar, yaitu bekerja secara aman di laboratorium, menggunakan peralatan sesuai dengan fungsinya, dan melaksanakan praktikum dengan benar sesuai dengan prosedur. Praktikum latihan hanya pembuktian dari konsep-konsep yang sudah ada tanpa merangsang mahasiswa untuk menemukan sendiri konsep baru dan tidak menantang untuk melakukan inovasi (Kurniawati et .al, 2015). 


\section{SIMPULAN}

Berdasarkan hasil penelitian dapat disimpulkan peningkatan intensi berwirausaha mahasiswa yang memperoleh pembelajaran dengan penerapan model pembelajaran berbasis proyek pada praktikum budidaya Maggot BSF lebih baik daripada praktikum konvensional. Penerapan model pembelajaran berbasis proyek dalam praktikum diharapkan dapat meningkatkan intensi berwirausaha mahasiswa sehingga siap untuk praktik usaha berbekal ilmu biologi terapan yang dimilikinya.

\section{UCAPAN TERIMAKASIH}

Penulis mengucapkan terima kasih kepada Program Studi Biologi, Fakultas Keguruan dan Ilmu Pendidikan (FKIP) Universitas Galuh, Lembaga Penelitian dan Pengabdian Masyarakat (LPPM) Universitas Galuh, serta DPRM Kementerian Riset, Teknologi, dan Pendidikan Tinggi (Kemenristekdikti) yang telah memberikan dukungan dan dana kegiatan penelitian.

\section{REFERENSI}

Afifi, R dan Yulisma, L. 2019. Project Based Learning Application to Develop Entrepreneurship of Preservice Teacher. Journal of Physics: Conference Series, VOL 1157 (2).

Agustina, P. 2015. Persepsi Mahasiswa Calon Guru Biologi tentang Pengembangan Praktikum Biologi Sekolah Menengah : Studi Pengembangan Pembelajaran Pada Mahasiswa Pendidikan Biologi FKIP Universitas Muhammadiyah Surakarta. Jurnal Bioedukatika. Vol 3 (2). Hal : 2629

Bae, et, al. 2014. The relationship between entrepreneurship education and entrepreneurial intentions: A metaanalytic review. Journal Entrepreneurship Theory And Practice, Vol 38 (2). Hal : 217-254.

Bas, G. 2011. Investigating The Effects of Project Based Learning on Students Academic Achievement And Attitudes Towards English. TOJNED: The Online Journal of New Horisozon In Education. Vol. 1 (4).
Čičková H, et.al. 2015. The Use of Fly Larvae for Organic Waste Treatment. Waste Manag. Vol 35. Hal : 68-80.

Darmawan, I, Suetjipto, B. E. 2016. The Implementation of Project Base Learning to Improve entrepreneurrial intention and entrepreneurship learning out come of Economics Education Student. IOSR Journal of Business and Management. Vol 18 (10). Hal : 98-102

Farida, E et.al. 2017. Pengembangan Model Pembelajaran Kewirausahaan Berbasis Proyek untuk Menumbuhkan Semangat Wirausaha Mahasiswa Prodi Pendidikan Ekonomi IKIP PGRI Bojonegoro. JPEK. Vol 1(1). Hal : 8-13.

Gerba, D.T. 2012. Impact of entrepreneurship education on entrepreneurial intentions of business and engineering students in Ethiopia. African Journal of Economic and Management Studies. Vol. 3(2). Hal : 258-277.

Handaru, A.W., et. al. 2015. Membangun Intensi Berwirausaha Melalui Adversity Quotient, Self Efficacy, dan Need For Achievement. Jurnal Manajemen dan Kewirausahaan. Vol.17 (2), Hal : 145166.

Jagantara, I.M.W, Adnyana, P.B dan Widiyanti, N.L.P. 2014. Pengaruh Model Pembelajaran berbasis proyekterhadap Hasil Belajar Biologi Ditinjau dari Gaya Belajar Siswa SMA. E-Journal Program Pascasarjana Universitas Pendidikan Ganesha Program Studi IPA. Vol 4 (1). Hal : 1-13.

Kemdikbud. 2014. Materi Pelatihan Guru Implementasi Kurikulum 2013 Mata Pelajaran IPA. Jakarta : Kementrian Pendidikan dan Kebudayaan. Hal. 34.

Kurniawati, L., et. al. 2015. Pengaruh Penerapan Metode Pembelajaran Praktikum Terhadap Keterampilan Berpikir Kritis Matematika Siswa. Jurnal Eduma. Vol 4(2). Hal : 62-74.

Kusumaningrum, S. dan Djukri, D. 2016. Pengembangan Perangkat Pembelajaran Model Project Based Learning (PjBL) untuk Meningkatkan Keterampilan Proses Sains dan Kreativitas. Jurnal 
Quagga: Jurnal Pendidikan dan Biologi

Volume 12, Nomor 1, Januari 2020, pp.17-23

Inovasi Pendidikan IPA. Vol 2 (2) . Hal : 241-251.

Muhar, A.M. 2013. Faktor Penentu Intensi Berwirausaha di Kalangan Mahasiswa Perguruan Tinggi Negeri. Jurnal Keuangan dan Bisnis. Vol 5 (1). Hal : 15-29.

Mulyani, E. 2014. Pengembangan Model Pembelajaran berbasis proyekPendidikan Kewirausahaan untuk Meningkatkan Sikap, Minat, Perilaku Wirausaha dan Prestasi Belajar Siswa SMK. Jurnal Cakrawala Pendidikan. Tahun XXXIII (1). Hal : 50-61 11.

Mulyana, M. 2012. Faktor-fakyor Yang Membentuk Intensi Berwirausaha Serta Pengaruhnya Terhadap Perilaku dan Kinerja Pedagang Kaki Lima di Kota Bogor. Diseminarkan dalam Kolokium Sekolah Pascasarjana IPB.

Otaya, L.G. 2014. Pengembangan Kurikulum Program Studi Pendidikan Islam Berbasis KKNI dalam Keterserapan Lulusan di Dunia Kerja. Jurnal Managemen Pendididkan Islam TARDIB. Vol 2 (1)

Sani, R. A. 2014. Pembelajaran Saintifik untuk Implementasi Kurikulum 2013. Jakarta: Bumi Aksara.

Singh, I., Prasad, T., \& Raut, R. D. 2012. Entrepreneurial intent-A review of literature. Proceedings of the Ninth AIMS International Conference on Management. Maharashtra, India.

Siwa, I.B, et.al. 2013. Pengaruh Pembelajaran Berbasis Proyek dalam Pembelajaran Kimia terhadap Keterampilan Proses Sains Ditinjau dari Gaya Kognitif Siswa. E-Journal Program Pascasarjana Universitas Pendidikan Ganesha Program Studi IPA. Vol 3 (1). Hal : 113.
p-ISSN 1907-3089, e-ISSN2651-5869

https://doi.org/10.25134/quagga.v12i1.2127

Suharti, L dan Hani, S. 2011. Faktor-faktor yang Berpengaruh terhadap Niat Kewirausahaan (Entrepreneurial Intention) : Studi terhadap Mahasiswa Universitas Kristen Satya Wacana Salatiga. Jurnal Managemen dan Kewirausahaan .Vol 13 (2). Hal: 124134.

Suryaman. 2014. Fun-Eco-Preneur Education : Sebuah Konsep Pendidikan Multibudaya untuk Memperkuat Nilai-nilai Wirausaha di Indonesia. Sosiohumanika. Vol 7 (1). Hal : 125-136.

Wardhana, A.H. 2016. Black Soldir Fly (Hermetia Illucens) sebagai Sumber Protein Alternatif untuk pakan ternak. Wartazoa. Vol 26 (2). Hal : 69-78 